\title{
Ingestion of polydextrose increase the iron absorption in rats submitted to partial gastrectomy ${ }^{1}$
}

\author{
A ingestão de polidextrose aumenta a absorção de ferro em ratos submetidos à gastrectomia \\ parcial
}

\author{
Elisvânia Freitas dos Santosi ${ }^{\mathrm{I}}$, Kathia Hitomi Tsuboi ${ }^{\mathrm{II}}$, Marina Rachel Araújo ${ }^{\mathrm{III}}$, Mônica Almeida Falconi ${ }^{\mathrm{IV}}$, Arthur C. Ouwehand ${ }^{\mathrm{V}}$, \\ Nelson Adami Andreollo ${ }^{\mathrm{VI}}$, Celio Kenji Miyasaka ${ }^{\mathrm{VII}}$ \\ ${ }^{1}$ Fellow Master degree, FEA, DEPAN, UNICAMP, Campinas-SP, Brazil.

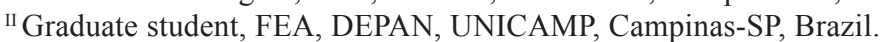

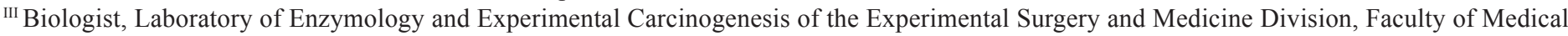 \\ Sciences, UNICAMP, Campinas-SP, Brazil. \\ ${ }^{\mathrm{IV}}$ Biologist, Hematologic Division, State University of Campinas, UNICAMP, Campinas-SP, Brazil. \\ ${ }^{v} \mathrm{PhD}$, Health \& Nutrition, Danisco, Finland. \\ ${ }^{\mathrm{V}}$ Full Professor, Digestive Disease Division, Department of Surgery, Faculty of Medical Sciences, UNICAMP, Campinas-SP, Brazil. \\ VII Assistant Professor, Center of Biological and Health Sciences, Cruzeiro do Sul University (UNICSUL), Sao Paulo-SP, Brazil.
}

\begin{abstract}
Purpose: To investigate whether polydextrose stimulates iron absorption in rats submitted to partial gastrectomy and sham operated. Methods: The rats were submitted to partial gastrectomy (Billroth II) or laparotomy (sham-operated control), in groups of 20 and 20 each respectively. The animals were fed with a control diet (AIN-93M) without polydextrose or a diet containing polydextrose $(50 \mathrm{~g} / \mathrm{Kg}$ of diet) for eight weeks. They were divided into four subgroups: sham-operated and Billroth II gastrectomy and with or without polydextrose. Two animals died during the experiment. All rats submitted to gastrectomy received B-12 vitamin (intramuscular) each two weeks. The hematocrit and hemoglobin concentration were measured at the start and on day 30 and 56 after the beginning of the experimental period. At the end of the study, the blood was collected for determination of serum iron concentration. Results: The diet with polydextrose reduced the excretion of iron. Apparent iron absorption was higher in the polydextrose fed groups than in the control group. The haematocrit and haemoglobin concentration were lower after Billroth II gastrectomy rats fed the control diet as compared to the polydextrose diet groups. Conclusion: Polydextrose increase iron absorption and prevents postgastrectomy anemia.
\end{abstract}

Key words: Prebiotics. Gastrectomy. Iron. Anemia. Rats.

\section{RESUMO}

Objetivo: Investigar se a polidextrose estimula a absorção de ferro em ratos submetidos à gastrectomia parcial e sham operados. Métodos: Os ratos foram submetidos à gastrectomia parcial (Billroth II) e à laparotomia (controle sham-operados) em grupos de 20 e 20 cada, respectivamente. Os animais foram alimentados com uma dieta controle (AIN-93M), sem polidextrose ou uma dieta contendo polidextrose $(50 \mathrm{~g} / \mathrm{kg}$ de dieta) durante oito semanas. Foram divididos em quatro grupos: sham-operados e com gastrectomia BII e com ou sem polidextrose. Dois animais morreram durante o experimento. Todos os ratos com gastrectomia receberam vitamina B-12 (intramuscular) a cada duas semanas. O hematócrito e a hemoglobina foram dosados no início e nos dias 30 e 56 após o início do período experimental. No final do estudo, o sangue foi coletado para determinação da concentração de ferro sérico. Resultados: A dieta com polidextrose reduziu a excreção de ferro e a absorção de ferro aparente foi maior nos grupos alimentados com polidextrose do que no grupo controle. As dosagens de hematócrito e hemoglobina foram menores em ratos com gastrectomia alimentados com a dieta controle em relação aos grupos de dieta com polidextrose. Conclusão: A polidextrose aumenta a absorção do ferro e previne a anemia pós-gastrectomia.

Descritores: Prebióticos. Gastrectomia. Ferro. Anemia. Ratos.

${ }^{1}$ Research performed at the Postgraduate Program, Department of Food and Nutrition (DEPAN), Faculty of Food Engineering (FEA) and Laboratory of Enzymology and Experimental Carcinogenesis, Faculty of Medical Sciences, State University of Campinas (UNICAMP), Sao Paulo, Brazil. 


\section{Introduction}

The iron is a main element in the terrestrial crust and it is an essential nutrient for all living organisms. However, in spite of it is abundance, it is poorly and biologically available, except in acid solution ${ }^{1}$.

The total or partial gastrectomy is indicated in the surgical treatment of gastroduodenal diseases, including the gastric cancer. The gastrointestinal transit after the partial gastrectomy is recovered through anastomosis with the duodenum (Billroth I-BI) or the jejunum (Billroth II-BII). The partial or total resection of the stomach includes the removal of the whole antrum decreasing the production of hydrochloric acid $(\mathrm{HCl})$, intrinsic factor and changes the gastric and duodenal function, lowering the absorption of the iron ${ }^{2}$.

Prebiotics are compounds which are not hydrolyzed nor absorbed in the upper gastrointestinal tract. They reach the large intestine intact, where they serve as substrate for bacterial metabolism ${ }^{3}$, promoting the proliferation of among others bifidobacteria and the synthesis of short chain fatty acids ${ }^{4}$.

The polydextrose is not hydrolyzed in the intestine after oral administration ${ }^{5}$. It is fermented in the large intestine producing short chain fatty acids and $\mathrm{CO}_{2}$ and part is excreted in the feces ${ }^{6}$. Polydextrose increases the volume of fecal mass, reduces the intestinal transit time, softens the stool and reduces fecal $\mathrm{pH}$. The fermentation leads to symbiotic the growth of favorable members of the microbiota, and suppresses the production of carcinogenic metabolites ${ }^{7}$.

The reduction of the faecal $\mathrm{pH}$ and the observation that prebiotics can improve the absorption of minerals such as calcium and magnesium led us to hypothesize that ingestion of prebiotic polydextrose could increase the bioavailability of dietary iron.

This hypothesis was assessed by investigated the effect of the polydextrose supplementation on the absorption of iron in rats submitted to partial gastrectomy.

\section{Methods}

Forty male Wistar rats (Cemib/Unicamp, Campinas, Brazil) $250.0 \pm 5 \mathrm{~g}$ of body weight were kept in collective cages in a room with controlled temperature $\left(22 \pm 1^{\circ} \mathrm{C}\right)$, humidity $(60-70 \%)$, cycle of 12 hours day-night (lights on at 7:00 am), with diet and deionized water ad libitum. The animals were randomly assigned to two groups of 20 animals each. Twenty animals were submitted to anterior truncal vagotomy and to partial gastrectomy (Billroth II). The sham group (twenty animals) were submitted to the same surgical stress, where the abdominal cavity was maintained open for approximately 45 minutes, which it is the duration of a gastrectomy. The rats were anesthetized with sodic thiopental ( $25 \mathrm{mg} / \mathrm{Kg}$ body weight, intravenous). The experimental protocol was previously approved by the Committee of Ethics in Animal Experimentation (CEEA) of the State University of Campinas UNICAMP (record nº. 839-1, 08/06/2005).

\section{Experimental groups and diets}

After 15 days of the procedure, the rats were divided randomly into four experimental subgroups (sham-operated vs. gastrectomy, control vs. polydextrose diet), (Sham/Control: $n=10$; Sham/PDX: $n=10$; Gastrectomy/Control: $n=9$; Gastrectomy/ PDX: $n=9)$. Two rats of the groups gastrectomy died during the experiment. They were fed the assigned experimental diets for eight weeks. The control and experimental were prepared according to the AIN-93M formulation by eight weeks ${ }^{8}$. Polydextrose (Litesse Ultra, Danisco Brazil Ltda, Cotia, Sao Paulo, Brazil) was added at $50 \mathrm{~g} / \mathrm{Kg}$ diet by replacing sucrose in the control diet.

Table 1 shows the composition of the two experimental diets (control and PDX). One-half of the rats submitted to gastrectomy and sham-operated rats were fed the control diet, and the remaining rats were fed the polydextrose diet.

TABLE 1 - Composition of experimental diet

\begin{tabular}{lcc}
\hline Ingredients, g/Kg & Control diet & PDX $^{\mathbf{1}}$ diet \\
\hline Cornstarch $^{\mathbf{2}}$ & 466 & 466 \\
Dextrinized cornstarch $^{2}$ & 155 & 155 \\
Casein $^{3}$ & 140 & 140 \\
Soybean oil $^{4}$ & 40 & 40 \\
Cellulose $^{\mathbf{5}}$ & 50 & 50 \\
Sucrose $^{\mathbf{6}}$ & 100 & 50 \\
Polydextrose $^{\mathbf{1}}$ & 0 & 50 \\
Mineral mixture $^{7}$ & 35 & 35 \\
Vitamin mixture $^{7}$ & 10 & 10 \\
L-Cystine $^{\mathbf{8}}$ & 1.8 & 1.8 \\
Choline bitartrate $^{9}$ & 2.5 & 2.5 \\
Tert-butylhydroquinone $^{\mathbf{1 0}}$ & 0.008 & 0.008
\end{tabular}

${ }^{1}$ Polydextrose (PDX, 50g/Kg diet) Litesse Ultra, Danisco Brasil Ltda, Cotia, Sao Paulo, Brazil. Refined polydextrose powder.

${ }^{2}$ Cornstarch and dextrinized cornstarch (Corn Products Brazil Ingredients Industrys Ltda, Mogi Guaçu, Sao Paulo, Brazil).

${ }^{3}$ Plury Chemistry Ltda, Diadema, Sao Paulo, fabricate by Naarden Agro Products-Holland.

${ }^{4}$ Mark Liza, Cargill do Brazil, Uberlandia, Minas Gerais, Brazil. ${ }^{5}$ Mark Microcel, Blanver Pharmachemistry Ltda, Cotia, Sao Paulo, Brazil.

${ }^{6}$ Refinery Uniao, Assis, Sao Paulo, Brazil.

${ }^{7}$ Prepared according to the AIN-93M formulation (8). Formulate by M. Cassab Trade and Industry Ltda, Sao Paulo, Sao Paulo, Brazil.

${ }^{8}$ Mark Synth C1027.01.AE; Diadema, Sao Paulo, Brazil.

9,10 SIGMA Chemical Co., St. Louis, Mo, USA. 
The animals were allowed free access to deionized water throughout the experimental period. For the prevention of the megaloblastic anemia, the rats received supplements of vitamin B12 (Cianocobalamin/0.5mg/Kg/intramuscular) (Cianotrat 5000Institute Therapeutic Delta Ltda, Indaiatuba-SP, Brazil) every two weeks, beginning one week after surgery. In the Sham group received chloride of the sodium $0.9 \%$ (Sanobiol Ltda, Pouso Alegre-MG, Brazil).

For feces collection, the animals were placed into individual metabolic cages, for three days in three periods at $15^{\text {th }}$, $35^{\text {th }}$ and $55^{\text {th }}$ day of the experiment ${ }^{9}$.

The weight gain and the consumption of the diet of the animals were monitored three times a week, for eight weeks.

\section{Analytical methods}

The blood of the anesthetized animals was collected by retroocular vein puncture every fourth week during the experimental period. In the beginning of the experiments, the blood was collected from randomized animals before the surgery procedure. Blood samples were analyzed to determine the hematocrit and hemoglobin concentration using a hematological analyzer (Advia' ${ }^{\mathrm{TM}}$ 120, Bayer $^{\circledR}$, Ireland).

On the final day of the experiment, all rats were anesthetized with sodic thiopental $(25 \mathrm{mg} / \mathrm{Kg}$ body weight). Whole blood was collected by cardiac puncture, and the animals were sacrified.

The serum iron contents were determined by a commercially available colorimetric method (Laborlab, Guarulhos-SP, Brazil).

Freeze-dried feces were weighed and milled. Diets and the powdered feces were dry-ashed at linearly increased temperatures up to $550^{\circ} \mathrm{C}$ for $6 \mathrm{~h}$ and then at $550^{\circ} \mathrm{C}$ for $18 \mathrm{~h}$ by a muffle furnace (Fornitec Industry and Trade Ltda, Sao Paulo, Brazil). Samples were heated with $0.5 \mathrm{~mL}$ concentrate $\mathrm{HNO}_{3} 65 \%$ and $0.15 \mathrm{~mL}(30 \%) \mathrm{H}_{2} \mathrm{O}_{2}$ (Merck Brazil, Sao Paulo, Brazil) in closed pressurized Hostaflon tubes heated in microwave (DGT 100 Plus-Provecto). The determinations of fecal iron and diet were performed in an Optic Emission IRIS-AP (Thermo Jarrell Ash) at the specialized Laboratory of Biominerals Chemical Analyses, Campinas, Sao Paulo - Brazil and the calculations were: Apparent iron absorption $(\mathrm{mg} /$ day $)=$ iron intake $(\mathrm{mg} /$ day $)-$ fecal iron excretion (mg/day).

\section{Statistical analysis}

The results were submitted to analysis of variance (ANOVA), with the use of Duncan's test for the comparison of the averages. The data were analyzed by two-way (treatment and diet) or three-way (treatment, diet and time). Differences were considered significant at $p<0.05$. Data are expressed as means and standard error of mean (SEM). STATISTICA Ver 6.0 ${ }^{\circledR}$ (Statsoft, Inc. Tulsa, USA) for Windows ${ }^{10}$.

\section{Results}

\section{Body weight and food intake}

Initial body weight in both sham-operated feeding groups was significantly higher than those in the corresponding rats with gastrectomy $(p<0.05)$. Final body weights in both gastrectomy rat groups were significantly lower than those in sham-operated rats $(\mathrm{P}<0.05)$. However, total body weight gain (results not shown) was not significantly different between the sham and groups with gastrectomy $(p>0.05)$. Food intake in rats submitted to gastrectomy eating the control diet was significantly lower compared to the other three groups $(\mathrm{p}<0.05)$.

Each value in the Table 2 represents a mean \pm SEM. Values in a column not sharing a superscript letters were significantly different, $\mathrm{p}<0.05$ (Duncan's multiple range test).

TABLE 2 - Initial and final body weights and food intake of shamoperated and rats with gastrectomy fed diets with polydextrose (PDX) or without polydextrose (control)

\begin{tabular}{lccc}
\hline $\begin{array}{l}\text { Treatments/ } \\
\text { Diets }\end{array}$ & $\begin{array}{c}\text { Initial body } \\
\text { weight }(\mathrm{g})\end{array}$ & $\begin{array}{c}\text { Final body } \\
\text { weight }(\mathrm{g})\end{array}$ & $\begin{array}{c}\text { Food intake } \\
(\mathrm{g} / \text { day })\end{array}$ \\
\hline Sham & & & \\
Control $(\mathrm{n}=10)$ & $264.50 \pm 3.43 \mathbf{a b}$ & $421.60 \pm 7.66 \mathbf{a}$ & $25.84 \pm 2.48 \mathbf{a}$ \\
PDX $(\mathrm{n}=10)$ & $275.20 \pm 5.00 \mathbf{a}$ & $421.70 \pm 10.6 \mathbf{a}$ & $26.29 \pm 2.40 \mathbf{a}$ \\
& & & \\
Gastrectomy & & & \\
Control $(\mathrm{n}=9)$ & $221.88 \pm 4.74 \mathbf{c}$ & $375.00 \pm 9.94 \mathbf{b}$ & $21.02 \pm 1.10 \mathbf{b}$ \\
PDX $(\mathrm{n}=9)$ & $256.78 \pm 8.09 \mathbf{b}$ & $391.44 \pm 8.69 \mathbf{b}$ & $24.87 \pm 2.70 \mathbf{a}$ \\
\hline
\end{tabular}

\section{Humid and dry weight of feces}

The results are showed in the Table 3:

TABLE 3 - Weight wet and dry of the feces $(\mathrm{g})$ collected in 3 times (15, 35 and 55 days) of the experimental phase, for three days each period of the groups sham-operated and rats with gastrectomy fed diets with polydextrose (PDX) or without polydextrose (control)

\begin{tabular}{lll}
\hline Groups/Treatments & \multicolumn{3}{c}{ Weigh feces $(\mathrm{g})$} \\
& Weigh Wet $(\mathrm{g})$ & Weigh Dry $(\mathrm{g})$ \\
\hline Sham & & \\
Control $(\mathrm{n}=9)$ & $4.62 \pm 0.22 \mathbf{b}$ & $4.12 \pm 0.17 \mathbf{~ b}$ \\
PDX $(\mathrm{n}=9)$ & $6.08 \pm 0.42 \mathbf{~ a ~}$ & $5.01 \pm 0.26 \mathbf{~ a}$
\end{tabular}

\begin{tabular}{lll} 
Gastrectomy & & \\
Control $(\mathrm{n}=9)$ & $5.42 \pm 0.46 \mathbf{b}$ & $4.73 \pm 0.35 \mathbf{b}$ \\
$\operatorname{PDX}(\mathrm{n}=9)$ & $8.05 \pm 0.62 \mathbf{a}$ & $6.46 \pm 0.32 \mathbf{a}$ \\
\hline
\end{tabular}


In sham-operated and rats with gastrectomy, the mean wet and dry weight of the feces was significantly higher in rats that received the polydextrose diet then in rats that received the control diet $(\mathrm{p}<0.05)$. Each value in the Table 3 represents a mean \pm SEM. Values in a column not sharing a superscript letters were significantly different, $\mathrm{p}<0.05$ (Duncan's multiple range test).

\section{Hematocrit and hemoglobin concentration}

The starting hematocrit levels were the same for the sham and animals with gastrectomy (Figure 1).

\begin{tabular}{ll|}
$\multimap-$ Sham/Control & - -Sham/PDX \\
$\longrightarrow$ Gastrectomy/Control & $\longrightarrow$ Gastrectomy/PDX
\end{tabular}

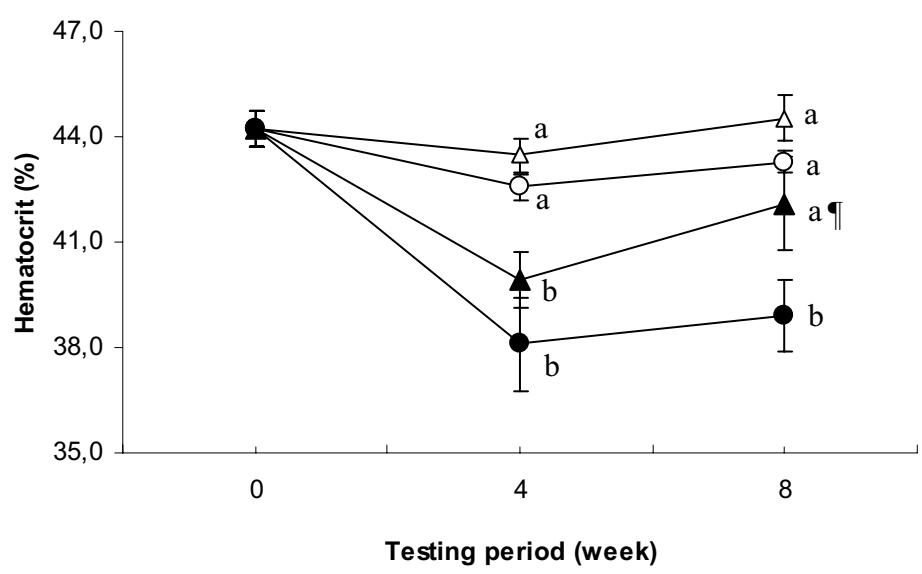

FIGURE 1 - Hematocrit concentration in sham operated or with gastrectomy rats fed diets with polydextrose (PDX) or without polydextrose (control), at 0,4 and $8 \mathrm{wk}$ after the start of the feeding period. Each values represents the means \pm SEM (Sham/Control: $n=10$; Sham/PDX: n=10; Gastrectomy/Control: $n=9$; Gastrectomy/PDX: $n=9$ ). All ANOVA main effects (treatment, diet and time) were significant. Diet (control or PDX) treatment (with or without gastrectomy) and time (0, 4, 8 wk) significantly larger than in gastrectomy control (without polydextrose). Point not sharing a common superscript are significantly different, $\mathrm{p}<0.05$ (Duncan's multiple range test)

After four weeks in the experiment, the sham-operated rats showed higher hematocrit levels as compared to the animals with gastrectomy. In the eighth week, the hematocrit level of the these animals receiving polydextrose-diet, was higher than, as compared to the Billroth II gastrectomy receiving controlled-diet, not different from the sham-operated rats which received diet with or without polydextrose $(\mathrm{p}<0.05)$.
The starting hemoglobin levels were the same for the rats submitted to gastrectomy and sham-operated rats (Figure 2).

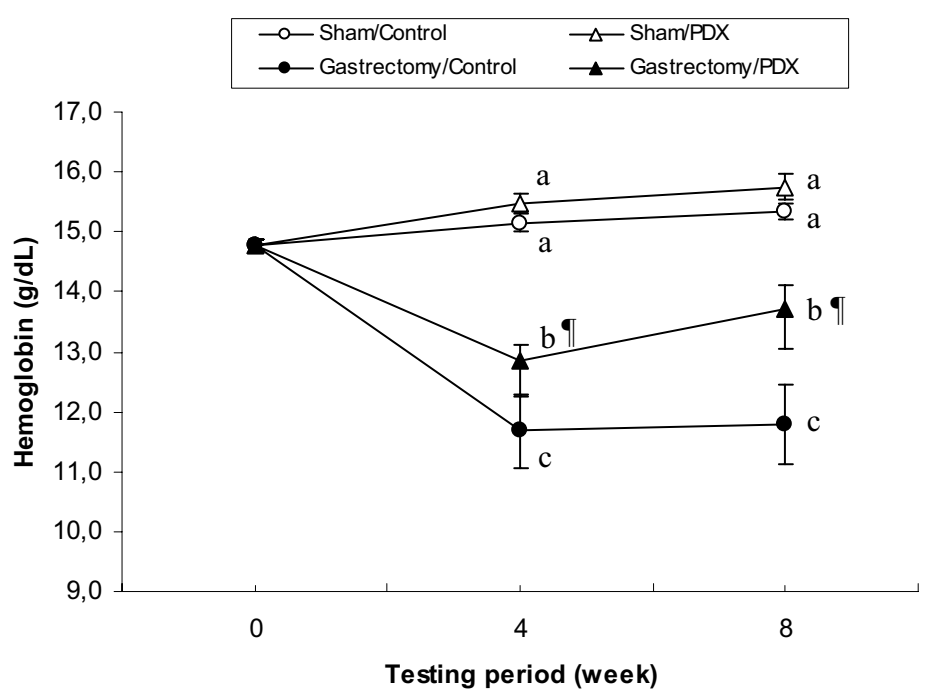

FIGURE 2 - Hemoglobin concentration in sham operated or rats with gastrectomy fed diets with polydextrose (PDX) or without polydextrose (control), at 0, 4 and $8 \mathrm{wk}$ after the start of the feeding period. Each values represents the means \pm SEM (Sham/Control: $n=10$; Sham/PDX: $\mathrm{n}=10$; Gastrectomy/Control: $\mathrm{n}=9$; Gastrectomy/PDX: $\mathrm{n}=9$ ). All ANOVA main effects (treatment, diet and time) were significant. Diet (control or PDX) treatment (with or without gastrectomy) and time $(0,4,8 \mathrm{wk})$ significantly larger than in gastrectomy control (without polydextrose). Point not sharing a common superscript are significantly different, $\mathrm{p}<0.05$ (Duncan's multiple range test)

In the fourth and eighth week of the experiment, the hemoglobin was higher in the sham-operated rats with control and polydextrose diet as compared to animals with gastrectomy $(\mathrm{p}<0.05)$, An increase was observed in the rats with gastrectomy receiving polydextrose enriched-diet as compared to the rats with gastrectomy and with control diet, this did, however, not reach statistical significance.

\section{Serum iron concentration}

The concentration of iron in the serum of sham-operated rats fed either control or polydextrose diet did not differ from each other but was significantly higher than those rats with gastrectomy fed either diet $(p<0.05)$. Serum iron in rats fed the polydextrose was higher than that in rats with gastrectomy fed the control diet, however this did not reach statistical significance (Figure 3). 
Fecal iron and apparent iron absorption

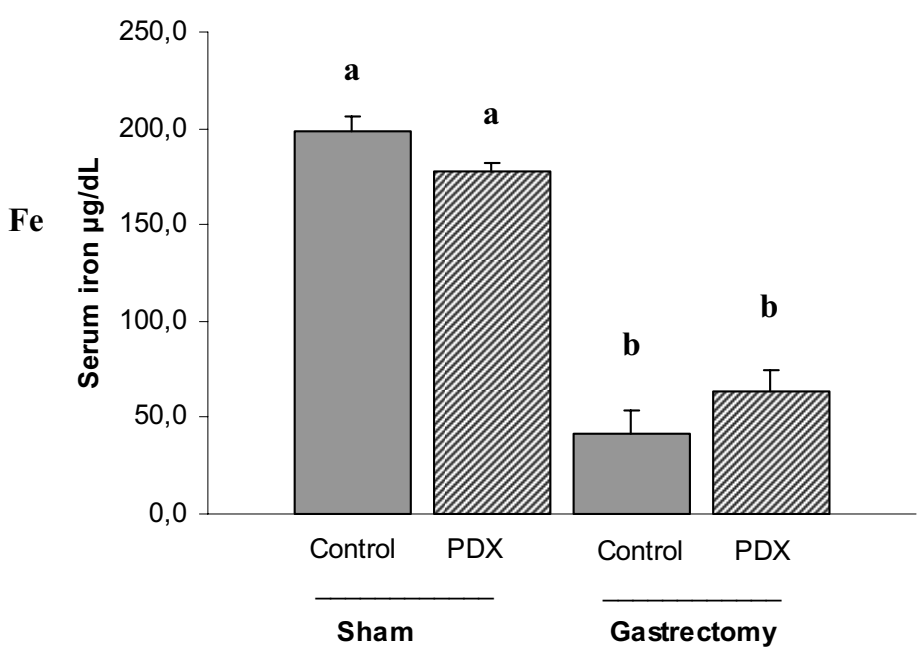

FIGURE 3 - Serum iron in sham operated or rats with gastrectomy fed diets with polydextrose (PDX) or without polydextrose (control). Each values represents the means \pm SEM (Sham/Control: $n=10$; Sham/PDX: $\mathrm{n}=10$; Gastrectomy/Control: $\mathrm{n}=9$; Gastrectomy/PDX: $\mathrm{n}=9$ ). Two ANOVA main effects (treatment and diet) and interactions (treatment $x$ diet) were significant. Diet (control or PDX) treatment (with or without gastrectomy). Bars not sharing a common superscript are significantly different, $\mathrm{p}<0.05$ (Duncan's multiple range test)

The concentration of iron in feces in the sham-operated rats and with gastrectomy receiving polydextrose enriched-diet was lower $(\mathrm{P}<0.05)$ as compared to the control diet (Figure 4).

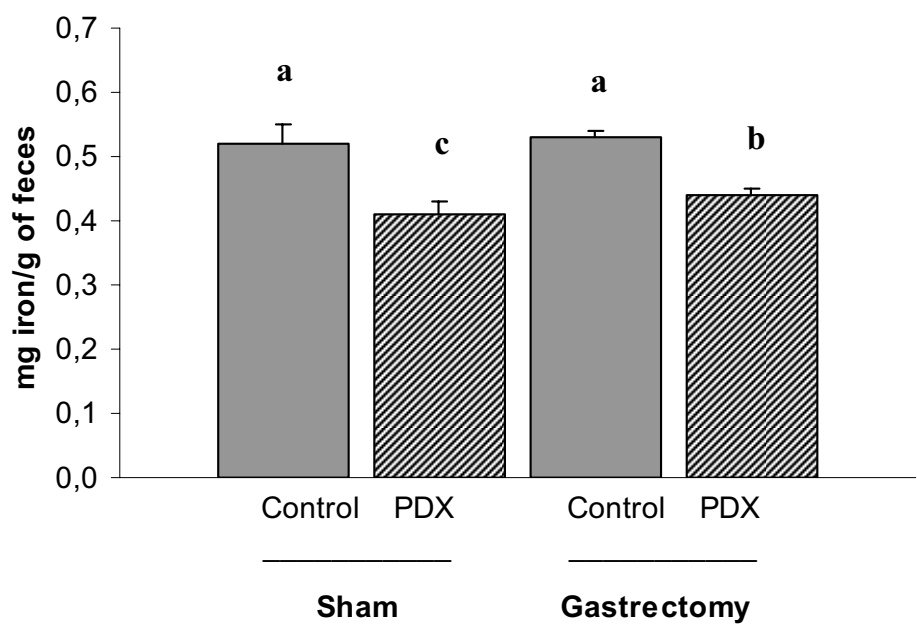

FIGURE 4 - Fecal iron concentration (mg/g feces) in sham operated or with gastrectomy rats fed diets with (PDX) or without (control) polydextrose. Each values represents the means \pm SEM (Sham/Control: $\mathrm{n}=10$; Sham/PDX: $\mathrm{n}=10$; Gastrectomy/Control: $\mathrm{n}=9$; Gastrectomy/PDX: $\mathrm{n}=9$ ). Two ANOVA main effects (treatment and diet) and interactions (treatment $x$ diet) were significant. Diet (control or PDX) treatment (with or without gastrectomy). Bars not sharing a common superscript are significantly different, $\mathrm{p}<0.05$ (Duncan's multiple range test)
The apparent absorption of iron by the sham-operated and rats with gastrectomy receiving polydextrose enriched-diet was higher as compared to the animals with normal diet (Figure 5). The sham-operated rats showed higher apparent absorption compared to the rats with gastrectomy, both receiving polydextrose or control-diet $(\mathrm{p}<0.05)$.

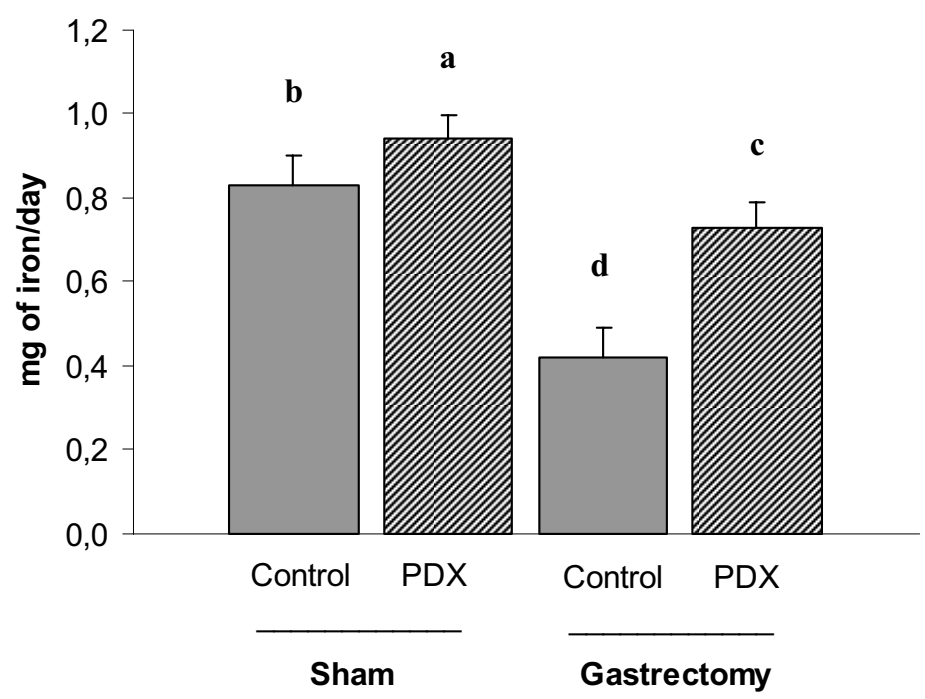

FIGURE 5 - Apparent iron absorption in sham operated or rats with gastrectomy fed diets with polydextrose (PDX) or without polydextrose (control). Each values represents the means $\pm \operatorname{SEM}$ (Sham/Control: $n=10$; Sham/PDX: n=10; Gastrectomy/Control: n=9; Gastrectomy/PDX: n=9). Two ANOVA main effects (treatment and diet) and interactions (treatment $\mathrm{x}$ diet) were significant. Diet (control or PDX) treatment (with or without gastrectomy). Bars not sharing a common superscript are significantly different, $\mathrm{p}<0.05$ (Duncan's multiple range test)

\section{Discussion}

The rat digestive system exhibits certain similarities to that of humans. Good correlations have been observed between work with rats as experimental animals and their comparison to humans ${ }^{11-14}$. The present study confirms observations on partial gastrectomy in adult rats where less feed consumption and smaller weight in animals with gastrectomy was reported ${ }^{15}$. That smaller weight gain of the rats with gastrectomy can be associated to the smaller feed consumption due to a smaller size of the stomach (Table 2). The fecal production increased significantly in rats fed with polydextrose (Table 3 ). An earlier study with rats submitted to gastrectomy found that after the procedure, metabolic changes occur that reduce the absorption of nutrients, causing a delay in growth of the animals ${ }^{16}$.

In rats with gastrectomy the hematocrit and hemoglobin were significantly lower than in the sham-operated rats (Figures 1 and 2). Similar results have been reported before, after gastrectomy ${ }^{15,17,18}$. Starting in the $4^{\text {th }}$ week of supplementation, the rats with gastrectomy that receiving polydextrose enriched-diet presented hematocrit concentration and hemoglobin levels significantly higher compared to the rats with gastrectomy that received the control diet (Figures 1 and 2). 
The polydextrose enriched-diet prevented the development of the anemia. The final concentration of hematocrit (eight weeks) in the rats with gastrectomy was not different from the sham-operated rats fed with any one of the diets (Figure 1). Similar effects have also shown by other researchers for other prebiotics $^{19-22}$.

The concentration of serum iron was decreased after the partial gastrectomy (Figure 3). The rats with gastrectomy fed with polydextrose presented the higher concentration of serum iron as compared to the rats that receiving control diet, however this did not reach statistical significance (Figure 3 ). In this respect, it is important to point out that there is a substantial positive correlation between the concentration of serum iron and the absorption of iron. Studies with fructooligosaccharides also presented an increased absorption of iron in deficient rats iron deficiency ${ }^{19}$, suggesting that this diet could prevent the anemia.

The excretion of iron in the feces was significantly higher in the sham-operated rats and in the animals with gastrectomy receiving controlled diet (without polydextrose) (Figure 4). The apparent absorption was lower after the partial gastrectomy (Figure 5). However, the sham-operated rats and rats with gastrectomy that received the polydextrose supplemented diet exhibited a significantly larger apparent iron absorption then their respective counter parts receiving the control (Figure 5). Our results suggests that the ingestion of polydextrose may reduce the risk for anemia due the increased the absorption of iron, since ingestion of polydextrose by both the sham-operated rats and rats with gastrectomy presented smaller excretion of iron in the feces and larger apparent absorption (Figures 4 and 5). Similar results for calcium have also been reported in rats submitted to the total gastrectomy ${ }^{16}$.

The results showed that the gastrectomy induced a severe deficiency of iron in the rats. The primary cause of this anemia was considered to be the blood lost during the surgical procedure, followed by the impaired absorption of iron (Figure 5) in rats with gastrectomy fed control diet, where the hemoglobin concentration decreased during the experimental period (Figure 2). In the present study rats with gastrectomy received B12 vitamin to prevent the pernicious anemia ${ }^{18}$. These results indicate that the anemia after gastrectomy observed in this study is anemia caused by iron deficiency.

Many authors have postulated that the reduced absorption of iron is caused by the lower intake after the gastrectomy ${ }^{15,23,24}$. The absorption of the iron occurs in all parts of the small intestine, but, mainly in the duodenum and proximal jejunum $^{25,26}$. In agreement, iron deficiency is observed in up to $70 \%$ of the patients with gastrectomy ${ }^{22,26}$. This fact added to the reduced gastric capacity and the absence hydrochloric acid increases the iron and other nutrients deficiencies ${ }^{15}$. Previous studies showed that the partial gastrectomy associated to anterior truncal vagotomy were a good experimental model to study the iron metabolism ${ }^{27}$ and calcium metabolism ${ }^{28}$.

The absorption of iron seems to occur not only in the small intestine, the large intestine appears to contribute to this absorption as well. However, the sufficient iron has been reported to be absorbed in the large intestine for recovery from anemia in iron deficient rats ${ }^{29,30}$. It has been showed that the proximal colon, can be an important site of iron absorption when the absorption in the small intestine is insufficient ${ }^{25,29,31}$, such as after the gastrectomy $^{32}$. Furthermore, animal studies have shown that the short chain fatty acids, in particular propionate seem to increase the absorption of iron in the colon proximal. This may indicate a potential mechanism whereby ingestion of prebiotics increases the bioavailability of dietary iron ${ }^{31}$.

An in vitro experimental model employing colonic fermentation showed that polydextrose administration increases the level of bifidobacteria and the level of short chain organic acids, in particular acetic acid. Furthermore, polydextrose reduced the levels of potentially pathogenic bacteria in the proximal colon $^{32}$. Consequently, we speculated that in our study the effect of the polydextrose in increasing the absorption of iron in rats after gastrectomy happened in the large intestine.

\section{Conclusion}

Polydextrose increase iron absorption and prevented anemia after partial gastrectomy in rats.

\section{References}

1. Miller DD. Minerals. In: Fennema OR. Food chemistry. 3ed. New York: Marcel Dekker; 1996.

2. Papini-Berto SJ, Burini RC. Causes of malnutrition in post-gastrectomy patient. Arq Gastroenterol. 2001;38: 272-75.

3. Rivero-Urgell M, Santamaria-Orleans A. Oligosaccharides: application in infant food. Early Hum Dev. 2001;65:S43-S52.

4. Crittenden RG, Playne MJ. Production, properties and applications of food-grade oligosaccharides. Trends Food Sci Technol. 1996;7:353-61. 5. Craig SAS, Holden JF, Troup JP, Auerbach MH, Frier HI. Polydextrose as soluble fiber: physiological and analytical aspects. Am Assoc Cereal Chem. 1998;43(5):84-8.

6. Yoshioka M, Shimomura Y, Suzuki M. Dietary polydextrose affects the large intestine in rats. J Nutr. 1994;124(4):539-47.

7. Zhong J, Luo B, Xiang M, Liu H, Zhai Z, Wang T, Craig SA. Studies on the effects of polydextrose intake on physiologic functions in Chinese people. Am J Clin Nutr. 2000;72(6):1503-9.

8. Reeves PG, Nielson FH, Fahey GCJR. AIN-93 purified diets for laboratory rodents: final report of the American Institute of Nutrition ad hoc writing committee on the reformulation of the AIN-76A rodent diet. J Nutr. 1993;123(11):1939-51.

9. Chonan O, Watanuki M. The effect of 6'-Galactooligosaccharides on bone mineralization of rats adapted to different levels of dietary calcium. Int J Vitam Nutr Res. 2003;66(3):244-9.

10. Statsoft, Inc. Statistica for Windows [Computer program manual]. Tulsa, USA, (2000) Available from http://www.statsoft.com

11. Gittes RF. Carcinogenesis in ureterosigmoidostomy. Urol Clin North Am. 1986;13(2):201-5.

12. Klee LW, Hoover DM, Mitchell ME, Rink RC. Long term effects of gastrocystoplasty in rats. J Urol. 1990;144(5):1283-7.

13. Iandoli Junior D, Nigro AJT, Sementilli A, Juliano Y, Novo NF. End-to-end esophagogastric anastomosis comparative study, between a single layer and submucosa-mucosa invagination technics in rats. Acta Cir Bras. [serial on the Internet] $2000 \mathrm{Jan}-\mathrm{Feb} ; 15(1)$. Available from URL: http://www.scielo.br/acb

14. Lambert R. Surgery of the digestive system in the rat. Illinois: Charles C. Thomas Publisher; 1965.

15. Ohta A, Ohtsuki M, Hosono A, Adachi T, Hara H, Sakata T. Dietary fructooligosaccharides prevent osteopenia after gastrectomy in rats. J Nutr. 1998;128(3):485-90. 
16. Hara H, Suzuki T, Aoyama Y. Ingestion of the soluble dietary fibre, polydextrose, increases calcium absorption and bone mineralization in normal and total-gastrectomized rats. Br J Nutr. 2000;84:655-61.

17. Sakai K, Ohta A, Shiga K, Takasaki M, Tokunaga T, Hara H. The cecum and dietary short-chain fructooligosaccharides are involved in preventing postgastrectomy anemia in rats. J Nutr. 2000;130(6):1608-12. 18. Shiga K, Nishimukai M, Tomita F, Hara H. Ingestion of difructose anhydride III, a non-digestible disaccharide, prevents gastrectomy-induced iron malabsorption and anemia in rats. Nutrition. 2006;22:786-93.

19. Ohta A, Ohtsuki M, Baba S, Adachi T, Sakata T, Sakaguchi EL. Calcium and magnesium absorption from the colon and rectum are increased in rats fed fructooligosaccharides. J Nutr. 1995;125:2417-24.

20. Ohta A, Sakai K, Takasaki M, Uehara M, Tokunaga T, Adachi T. Dietary heme iron does not prevent postgastrectomy anemia but fructooligosaccharides improve bioavailability of heme iron in rats. Int J Vitam Nutr Res. 1999;69(5):348-55.

21. Afsana K, Shiga K, Ishizuka S, Hara H. Ingestion of an indigestible saccharide, difructose anhydride III, partially prevents the tannic acidinduced suppression of iron absorption in rats. J Nutr. 2003;133:3553-60. 22. Shiga K, Hara H, Okano G, Aoyama Y. Ingestion of water-soluble soybean fiber prevents gastrectomy-induced iron malabsorption, anemia and impairment of voluntary running exercise performance in rats. J Nutr. 2003;133(4):1120-6.

23. Fischermann K, Harly S, Worning H. Pancreatic function and absorption of fat, iron, vitamin B12, and calcium after total gastrectomy for gastric cancer. Gut. 1967;8:260-6.

24. Boccio J, Salgueiro J, Lysionek A, Zulillaga M, Goldman C, Weill R, Caro R. Metabolismo del hierro: conceptos actuales sobre um micronutriente esencial. Arch Latino Am Nutr. 2003;53(2):119-32.

25. Campos MS, Gomez-Ayala AE, Lopez-Aliaga I, Pallares I, Hartiti S, Pharm B, Alferez M JM, Barronuevo M. Role of the proximal colon in mineral absorption in rats with and without ferropenic anemia. Nutr Res. 1996;16(9):1529-43.
26. Scholmerich J. Postgastrectomy syndromes - diagnosis and treatment. Best Pract Res Clin Gastroenterol. 2004;18(5):917-33.

27. Santos EF, Tsuboi KH, Palu BF, Araújo MR, Andreollo NA, Miyasaka CK. Effects of the partial gastrectomy associated to anterior truncal vagotomy in the metabolism of the iron in rats. Acta Cir Bras. 2008;23(5):401-4.

28. Santos EF, Tsuboi KH, Palu BF, Araújo MR, Andreollo NA, Miyasaka CK. Partial gastrectomy associated to anterior truncal vagotomy: alterations in metabolism of calcium. Experimental study in rats. ABCD Arq Bras Cir Dig. 2009;22(2)105-9.

29. Ebihara K, Okano J, Miyata T. Comparison of ferrous and ferric iron bioavailability following rat cecal infusion. Nutr Res. 1994;14(2):221-8.

30. Ebihara K, Okano J. Comparison of bioavailability and hemoglobin repletion of ferric and ferrous iron infused into the cecum in anemic rats. Nutr Res. 1995;15:889-97.

31. Bouglé D, Vaghefi-Vaezzadeh N, Roland N, Roland N, Bouvard G, Arhan P, Bureau F, Neuville D, Maubois JL. Influence of short-chain fatty acids on iron absorption by proximal colon. Scand J Gastroenterol. 2002;37(9):1008-11.

32. Probert HM, Apajalahti JHA, Rautonen N, Stowell J, Gibson GR. Polydextrose, lactitol, and fructo-oligosaccharide fermentation by colonic bacteria in a three-stage continuous culture system. Appl Environ Microbiol. 2004;70(8):4505-11.

\section{Acknowledgements}

Laboratory Biominerals Chemical Analyses Ltda and Johnson \& Johnson ${ }^{\circledR}$ for the surgical sutures.

Conflict of interest: none

Financial source: $\mathrm{CNPq}$

\section{Correspondence:}

Celio Kenji Miyasaka

Av. Monteiro Lobato, 80

Caixa Postal 6121

3.083-862 Campinas - SP Brasil

Phone: (55 19)3521-4078

Fax: (55 19)3521-4060

celiomiyasaka@gmail.com

Received: March 10, 2010

Review: May 11, 2010

Accepted: June 15, 2010

\section{How to cite this article}

Santos EF, Tsuboi KH, Araújo MR, Falconi MA, Ouwehand AC, Andreollo NA, Miyasaka CK. Ingestion of polydextrose increase the iron absorption in rats submitted to partial gastrectomy. Acta Cir Bras. [serial on the Internet] 2010 Nov-Dec;25(6). Available from URL: http://www.scielo.br/acb 